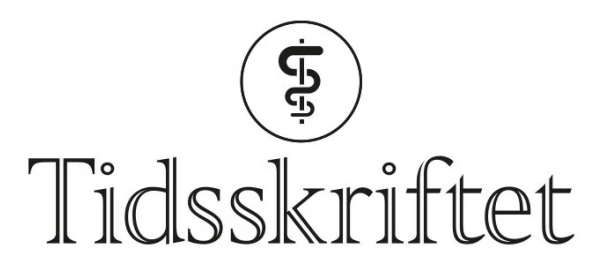

DEN NORSKE LEGEFORENING

\title{
Når covid-19 møter afrikansk helsevesen
}

LEDER

\section{MARIUS TRØSEID}

marius.troseid@medisin.uio.no

Marius Trøseid er spesialist i infeksjonssykdommer, overlege og førsteamanuensis ved Klinisk immunologi og infeksjonssykdommer, Oslo universitetssykehus, Rikshospitalet.

Forfatteren har fylt ut ICMJE-skjemaet og oppgir ingen interessekonflikter.

\section{Afrika sør for Sahara har lenge vært spart for covid-19, men pandemien kjenner ingen grenser. En solidarisk respons på pandemien er avgjørende for global helse, internasjonal økonomisk utvikling og vår alles sikkerhet.}

I vinter har jeg jobbet ved et sykehus i rurale Tanzania, i Manyara-regionen, seks timer sør for Arusha. Det føltes litt paradoksalt å reise fra et land nesten uten påviste koronatilfeller og hjem til karantene i pandemiens nye episentrum. Under mellomlandingen i Addis Abeba følte vi på et reelt og rasjonelt stigma: Europeere er mulige smittebærere, og afrikanerne holder avstand og dekker seg til med masker eller sjal. Smitten burde helst vært stoppet ved grensene, da muligheten for smittevern, diagnostikk og intensivbehandling er svært begrenset ved de fleste afrikanske sykehus. Vi ser nå at dette ikke er mulig. Covid-19 sprer seg overalt.

I løpet av februar og mars merket vi tydelig hvordan pandemien nærmet seg, og jeg ble involvert i opplæring og planlegging av covid-19-respons ved sykehuset. Men hvordan planlegge for isolering av pasienter når det allerede ligger 10-15 pasienter på hvert rom? Hvordan skille koronavirus fra lungebetennelse eller hjertesvikt uten virusdiagnostikk? Hvordan behandle intensivpasienter uten respirator, eller med oksygenkolber som jevnlig går tomme selv i en normalsituasjon? Hvordan vaske hender uten såpe eller håndsprit? Hvordan beskytte seg uten personlig smittevernutstyr? Og hvordan hindre at smittefrykt blant leger og sykepleiere fører til handlingslammelse og enda flere dødsfall? De fleste afrikanere har erfaring med to virusinfeksjoner, hiv og ebola, og mange frykter at koronaviruset skal være en like stor trussel (1). Den største trusselen er kanskje at et allerede overbelastet helsevesen risikerer å falle sammen. Det er viktig å legge gjennomførbare og tydelige planer, men evnen til å respondere varierer fra land til land (므). 
Det diskuteres i afrikanske og internasjonale medier om mulige årsaker til at Afrika så lenge har vært spart for pandemien. Det har vært spekulert i at viruset ikke trives like godt $\mathrm{i}$ varmt klima (3), selv om spredning av viruset i Thailand tyder på det motsatte. Mest sannsynlig ser vi en forsinkelse av pandemien, delvis grunnet geografisk avstand fra resten av verden og delvis strenge grensekontroller med temperaturmålinger og helsesjekk fra slutten av januar ved flere flyplasser. Mange land har inntil nylig vært i beredskap grunnet ebolaepidemien og iverksetter respons ut fra dette, selv om tiltakene varierer fra land til land og fra område til område. Flere og flere afrikanske land har stengt grensene for personer fra land med høy forekomst av covid-19. I Norge frarådes vi å reise til utlandet for å hindre at vi bringer smitte hjem igjen. Slik situasjonen er nå, er risikoen enda større for at nordmenn og andre europeere sprer viruset til land som ikke har ressurser til å håndtere en pandemi.

\section{«Mange barn har allerede mistet mor og far i hivepidemien og risikerer nå å miste besteforeldrene sine i covid-19-pandemien»}

Afrika sør for Sahara har en relativt ung befolkning, og det er mulig at viruset vil ramme mildere av den grunn. Men mange barn har allerede mistet mor og far i hivepidemien og risikerer nå å miste besteforeldrene sine i covid-19-pandemien. Og ingen vet hva som vil skje når covid-19 møter hiv- og tuberkulose-pandemien. Covid-19 er nå påvist i mer enn halvparten av kontinentets nasjoner. Algerie, Egypt, Sør-Afrika og stadig flere nasjoner har påvist innenlands spredning av viruset. Underrapporteringen er sannsynligvis stor grunnet manglende testkapasitet og diagnostikk. Sør-Afrika har erklært koronavirus som en nasjonal krise.

Hivepidemien satte utviklingen i Afrika sør for Sahara flere tiår tilbake. Den ga en sykdomsrammet befolkning, et overbelastet helsevesen og $ø$ konomisk resesjon. Dersom pandemien rammer så hardt som vi nå har grunn til å frykte, er det fare for at Afrika igjen blir liggende med brukket rygg. Hivepidemien var et altoverskyggende problem inntil tilgang til antiretroviral behandling stabiliserte situasjonen på kontinentet. Norske sykehus har nå startet å rekruttere pasienter til en WHO-koordinert behandlingsstudie av covid-19-pasienter, der blant annet malariamiddelet hydroksyklorokin skal prøves ut (4). Det er viktig at vi gjennomfører studien og rapporterer resultater så raskt som mulig, slik at ny behandling kan komme på plass, også i land som ellers vil ha store problemer med å bekjempe pandemien. Medisinsk forskning har aldri hastet mer enn nå.

Den internasjonale kampen om personlig smittevernutstyr er foruroligende. Det er forståelig at flere land har nok med å møte sine egne utfordringer, men behovet for internasjonal bistand under og etter pandemien må ikke undervurderes. Å svare kraftfullt og solidarisk på covid-19-pandemien er avgjørende for global helse, økonomisk utvikling og internasjonal sikkerhet. Dette gjelder vår felles trygghet.

\section{LITTERATUR}

1. Agyeman AA, Laar A, Ofori-Asenso R. Will COVID-19 be a litmus test for post-Ebola sub-Saharan Africa? J Med Virol 2020; 89. doi: 10.1002/jmv.25780. [PubMed][CrossRef]

2. Gilbert M, Pullano G, Pinotti F et al. Preparedness and vulnerability of African countries against importations of COVID-19: a modelling study. Lancet 2020; 395: 871-7. [PubMed][CrossRef]

3. Hopman J, Allegranzi B, Mehtar S. Managing COVID-19 in low- and middle-income countries. JAMA 2020;323. doi:10.1001/jama.2020.4169. [PubMed][CrossRef]

4. WHO 2020. Master Protocol. A Multi-centre, Adaptive, Randomized, Double-Blind, Placebo Controlled Clinical Trial of the Safety and Efficacy of Investigational Therapeutics for the Treatment of COVID-19 in Hospitalized Patients. 
Publisert: 6. april 2020. Tidsskr Nor Legeforen. DOI: 10.4045/tidsskr.20.0283

(C) Tidsskrift for Den norske legeforening 2023. Lastet ned fra tidsskriftet.no 26. april 2023. 